\title{
Malaysian Matriculation Student's Factors in Choosing University and Undergraduate Program
}

\author{
Norbahiah Misran ${ }^{1,2}$, Sarifah Nurhanum Syed Sahuri ${ }^{1,2}$, Norhana $\operatorname{Arsad}^{1}$, Hafizah Hussain ${ }^{1,2}$, Wan Mimi Diyana \\ Wan Zaki ${ }^{1} \&$ Norazreen Abd Aziz ${ }^{1}$ \\ ${ }^{1}$ Department of Electrical, Electronic and System Engineering, Universiti Kebangsaan Malaysia, Selangor, \\ Malaysia. \\ ${ }^{2}$ Center for Engineering Education Research, Universiti Kebangsaan Malaysia, Selangor, Malaysia \\ Correspondence: Norbahiah Misran, Department of Electrical, Electronic and System Engineering, Universiti \\ Kebangsaan Malaysia, 43600 UKM Bangi, Selangor, Malaysia. Tel: 60-3-8921-6335. Email: bahiah@gmail.com
}

Received: October 5, 2012 Accepted: November 23, 2012 Online Published: November 30, 2012

doi:10.5539/ass.v8n16p222 URL: http://dx.doi.org/10.5539/ass.v8n16p222

\begin{abstract}
The purpose of this study is to identify the influencing factors in selecting a university and course program among Malaysian matriculation students. The study was conducted at two matriculation colleges in south Malaysia. Questionnaire was distributed to students from Negeri Sembilan Matriculation College (NSMC) and Malacca Matriculation College (MMC). These matriculation students are selected because they are in the position of making decision to pursue their studies at tertiary level upon completing the matriculation program. The numbers of students from the matriculation program that pursue to the Malaysia Higher Learning Institutions (HLIs) are comparatively higher than the numbers of students from Malaysia Certificate of Higher Education (MCHE) and diploma program. The study found that the suitability of study program with their personalities, career opportunities and interest were significantly influenced them in choosing the university and course program. Therefore, some strategies and efforts are recommended for the engineering faculty of UKM to acquire better students in the future.
\end{abstract}

Keywords: students' decision, matriculation, engineering program, university

\section{Introduction}

In the Third Outline Perspective Plan (OPP3), the Malaysia government estimates about 137,200 engineers and 331,700 assistant engineers to be produced in 2010 which will be employed in various fields such as civil, mechanical, electrical and electronics, chemical, and others (Economic Planning Unit, 2001). It is speculated that the country needs 4,808,400 educated employees by 2020 in order to achieve Vision 2020 that was inspired by Tun Dr. Mahathir Mohamad, the fourth Prime Minister of Malaysia (Ministry of Higher Education, 2007). Consequently, Ministry of Higher Education (MOHE) was given huge responsibilities to achieve the vision. To date, there are 20 public Higher Educational Institutes (HEIs) in Malaysia and from that, 14 institutions offer accredited engineering programs (Engineering Accreditation Council, 2011). Apart from that, some private universities and colleges are also offering first degree in engineering programs. In gender aspect, the numbers of female students who enrolled in the public universities are more than the numbers of male students, but these numbers are reducing for technical-oriented course programs (Mustapha \& Long, 2010).

Universiti Kebangsaan Malaysia (UKM) was established in 1970 and one out of five Research Universities in Malaysia with eight faculties in total. Among these faculties, the Faculty of Engineering and Built Environment (FEBE) offers engineering and architecture programs to UKM students. Every year, the FEBE receives lot of applications from Malaysia Certificate of Higher Education (MCHE), diploma and matriculation graduates through University Center Unit (UCU) to be enrolled in the programs offered at undergraduate level according to their results. Tough competitions arise when large numbers of applicants choose for the same university or programs which make it hard for the students and the university to make the best choice.

The number of students enrolled in the FEBE for 2010/2011 session was 259 students in a range of programs comprising civil, electric and electronic and system, chemical, mechanical and architecture. The students were $140(54 \%), 85(33 \%), 31(12 \%)$ and $3(1 \%)$ from the matriculation, MCHE, special case and others, respectively. 
Surprisingly, $8 \%$ of the students did not choose engineering programs in their UCU application while $54 \%$ chose engineering programs in the first ranked, $16 \%$ in the second ranked, $14 \%$ in the third ranked, $4 \%$ and $2 \%$ in the fourth and fifth ranked, respectively (Universiti Kebangsaan Malaysia, 2010). This raises interesting questions on how the students make the decision in choosing a university and program especially for the students who were from the matriculation program because they made up the majority number of students enrolled in engineering programs in the FEBE. An initial study was conducted involving the matriculation students in order to understand the current trend of student's decision making (Misran et al., 2011).

Matriculation program has been established 30 years ago and it was initially conducted by some public HLIs. In 1998, Ministry of Education (MOE) has taken over the matriculation program from the HLIs and it was facilitated by Matriculation Division. The main function of this program is to prepare students to pursue their first degree in science, technology and accounting fields at local or overseas universities. MOHE together with MOE constructed the education system and learning syllabus.

It is essential to understand the conditions at that particular level in making decisions such as the correlation between personality and the choice of career interests (Albion \& Fogarty, 2011). In this paper, the questions to be answered are: i) what are UKM reputations from the view of the prospective applicants? ii) based on gender, what sorts of interest that the matriculation students have towards engineering programs at UKM? and iii) what are the factors influencing the matriculation students in choosing the university and course program.

\section{Literature Review}

The matriculation students are consisting of Malaysia Certificate of Education (MCE) holders. Their ages are between 16 to 19 years old. After completing one or two- years study program, they have to choose the university to pursue their studies at undergraduate level. Therefore, the questions should be first considered by these students are which university to choose and what program to attend to.

Von Mizener and William (2011) conducted the study on the effects of student's choice on academic performance and the result showed that the academic performance degraded if the student did not have goals in the selection. Meanwhile, Matusovich, Streveler and Miller (2010) stated that it was difficult to recruit and train the future engineers if they did not understand their goals, objectives, and criteria in the decision making process. It could be anticipated that individual student's objective would determine how they perform throughout the study.

Since the students of the matriculation program is made up from male and female, the gender is a psychological aspect that affects the decision making process and allows them to establish individual differences. There were differences in decision making process between male and female students but there was no sex difference in cognition and self regulation (Sanz de Acedo, Sanz de Aced and Cardelle- Elawar, 2007). Female students are more concerned with the uncertainty, doubts and the dynamism of the decision. They assess the risk of the decision and always put their emotion first. Male students are more focused on the information required to carry out the decision and the purpose of the decision. Hence, the male students are more objective-oriented and realistic.

Mastor (2006) discovered that introvert trait in Malay students' personality also affect their decisions. Female students who were more introvert than male students went through a tough process and were not always satisfied with their decisions. The students also claimed that they had such difficulties due to lack of encouragement or support from family members, friends, teachers and the environment (Mustapha and Long, 2009). Consequently, they developed into emotional-depression and confusion as compared to their male counterparts.

A study was conducted in United Arab Emirates (UAE) to identify female students' interest towards engineering programs. The female students showed that parents supports, established mathematical skills, sufficient university information and career opportunities influenced them to study engineering (Mahani and Molki, 2011). In Bostwana, there are five influencing factors for the female students to study engineering programs such as interest, career opportunities, skills in mathematics and science, income and their aspiration to develop the women well-being in their country (Baryeh, Squire \& Mogotsi, 2011).

\subsection{Influencing Factors}

Many factors influence students' decision making to pursue their studies at the HEIs and choose engineering programs. Seymour and Hewitt (1997) suggested that interest was the strongest element that affected students' decision. Most of the studies also showed similar results which interest was of the key factors in choosing a study program or career (Mahani \& Molki, 2011; McInnis, James \& Hartley, 2000). According to Mustapha and Long (2010), the students would take serious effort and give a full commitment if they were really interested to 
do something. On the other hand, if the students were not fascinated with their study programs, they would withdraw from the programs or perform badly (Yorke, 1999; Christie, Munro \& Fisher, 2004).

Consequently, it is important to the students to choose the right study programs that suit with their personalities because the chosen programs are closely correlated to their career paths in the future. Based on the Holland career theory (Noah, 2008), he suggested that individual personality traits should be matched with the environment characteristics. For example, individuals who were in the engineering or technical fields should have realistic characters such as stable, natural, masculine, practical, independent and materialistic (Mustapha and Long, 2010).

Duffy and Sedlacek (2011) had conducted a study on career choice that emphasized on the work value among first year students for 10 years. The work value was defined as the general output desired by an individual and the work components that give a job satisfaction to the individual. The work value between male and female were very different. Male was more interested with the money, position, or recognition. Meanwhile, female was more concerned about human relations and helping others (Abu-Saad \& Isralowitz, 1997; Duffy \& Sedlacek, 2007).

Many researchers found that influences from family and friends were among the most powerful factors in the decision making among Asian students to pursue their studies. Jusoh (2006) reported that the influences from former graduates and their parents became the most significant factors among the matriculation students in choosing local universities. However, a study conducted by Wagner and Fard (2009) found that these factors were not significantly affected the Malaysian students but this study was only involving colleges' students in Klang Valley and could not represent the whole population of pre-university students in Malaysia.

Socio-economic status (SES) also affects student's decision making process. SES was divided into three categories i.e. parents' education, parents' occupation and family size (Looker \& Lowe, 2001). According to Othman (2006), parents' education was an important element because educated parents would become more concerned with their children education needs. Parents' occupation influences their abilities to provide the basic needs for their family members. Thus, the students able to be more confident in making the decision to enrol at the HEIs as their needs have already been fulfilled.

University factors are among the various aspects that could affect students' decision making. Ming (2010) listed several aspects such as university location, programs offered, university reputation, university facilities, cost of education, financial assistance, job opportunities, advertising or information dissemination, representative of the university and campus tours as the university factors. Theoretically, all aspects have significant positive relationships with the chosen university. For example, in Jordan, the cost of education was the major factor in making the decision (Shammot, 2011). In Malaysia, the university's reputation, location and facilities were subject of considerations for the students in making decisions (Hassan, 2008). While, the content of the programs and the entry requirements of the university also became among the most influence factors (Wagner \& Fard, 2009; Othman, 2006).

Considering the above aspects, this study is looking at the trend of decision making among the matriculation students based on gender to represent the pre-university students as these students are from all over Malaysia.

\section{Methods}

\subsection{Instrument}

A questionnaire was developed to study the university's reputation and the factors influencing student's selection. It comprised four parts i.e. PART A) demographic of the respondent, PART B) the reputation of the university and engineering studies at UKM, PART C) student's interest in the engineering programs at UKM and PART D) factors to choose the universities and programs of study. Analysis from PART B) and PART C) which were the subjects of discussion in this paper, would be associated with the analysis in PART D).

The instrument was proved to have a very high level of reliability for all 36 items with coefficient $\alpha=0.89$ using Cronbach's Alpha reliability analysis. The value of the $\alpha$ coefficient indicated that this instrument had high level of consistency and reliability in measuring the constructs (Sam \& Mang, 2010).

It was found that if several items were deleted from the questionnaire, the value of the $\alpha$ coefficient remained high at about $\alpha=0.88$. Thus, this indicated that the whole items were very important to the instrument. The constructs validity was measured as the type of validity in order to describe the accuracy of the instrument to measure the items based on the theory involved (Sam \& Mang, 2010). The validity of the questionnaire was analysed by Statistical Package for Social Science version 19.0 (SPSS 19.0) using factor analysis. 
Bartlett's Test of Sphericity was 5614.08 at level of significant of 0.00 , demonstrating that there was a significant correlation between the variables and the result of Measure of Sampling Adequacy was at 0.88. Eight factors with eigenvalues $\geq 1.0$ were generated using the Principal Component Analysis and Varimax factor rotation. Three of the factors were integrated factors and the remaining factors were single factors. Therefore, this survey signified a high validity of the constructs in measuring the factors that influence students to choose university and programs.

\subsection{Participant and Procedure}

496 matriculation students were recruited from Negeri Sembilan Matriculation College (NSMC) and Malacca Matriculation College (MMC) in 2011/2012 session for this survey. The questionnaire was distributed through the Counselling Unit of the colleges and duration of 30 minutes was given for them to answer the questionnaire. Answers from each question were measured in five Likert scale which 1 and 5 indicated least influenced and strongly influenced, respectively. A positive response was considered when the answer was on a scale of 4 and 5 .

\subsection{Analysis}

The researchers analyzed all data using the SPSS 19.0 software. Descriptive test and mean comparison test were among the tests used to analyze the data. The analysis started with the demographic distribution of the matriculation students, followed by the students' perceptions on the reputation of UKM and engineering programs in UKM, and the selection factors of university together with programs of study.

\section{Result}

Table 1 showed the descriptive demographic distribution of the respondents from both of the colleges by gender, ethnics and education levels of the parents. The respondents were $64.30 \%$ female and $35.70 \%$ male. They were $87.90 \%$ Malay, $8.50 \%$ Chinese, $3.20 \%$ Indian, and $0.40 \%$ others. More than half $(52.90 \%)$ of the parents or guardians of the respondents had education qualifications up to the MCE level. This demonstrated that the respondents' SES level were moderate. $34.30 \%$ of the respondents were agreed to pursue their studies at the HLIs while the remaining respondents were disagreed and not sure.

Table 1. Demographic of the study's sample

\begin{tabular}{|c|c|c|c|}
\hline Demographic & Category & Number (n) & Percent $(\%)$ \\
\hline \multirow[t]{2}{*}{ Gender } & 1. Male & 177 & 35.70 \\
\hline & 2. Female & 319 & 64.30 \\
\hline \multirow[t]{4}{*}{ Ethnic } & 1. Malay & 435 & 87.90 \\
\hline & 2. India & 16 & 3.20 \\
\hline & 3. Chinese & 42 & 8.50 \\
\hline & 4. Other & 2 & 0.40 \\
\hline \multirow{6}{*}{$\begin{array}{l}\text { Highest education of } \\
\text { mother / father / } \\
\text { guardian }\end{array}$} & 1. SPM & 267 & 55.50 \\
\hline & 2. Certificate / Diploma & 70 & 6.14 \\
\hline & 3. Bachelor & 63 & 1.13 \\
\hline & 4. Master's degree & 38 & 7.90 \\
\hline & 5. Doctor of Philosophy & 11 & 2.30 \\
\hline & 6. Other & 32 & 6.70 \\
\hline \multirow[t]{3}{*}{ Entering HLI } & 1. Yes & 170 & 34.30 \\
\hline & 2. No & 116 & 23.40 \\
\hline & 3. Not sure & 210 & 42.30 \\
\hline
\end{tabular}

\subsection{Reputation of UKM and Engineering Programs}

Next analysis was to examine the respondents' perceptions towards the reputation of UKM and its engineering programs. Independent sample T-test was used according to gender as depicted in Table 2. The responses between the male and female respondents were significantly different for all items measured, except for the item regarding the existence of UKM as a public Higher Learning Institution in Malaysia with $\mathrm{t}(242.58)=-3.09, p$ $<0.05$. 
Table 2. Perception of the respondents on the UKM reputations and engineering programs

\begin{tabular}{llllllll}
\hline PART B & Gender & M & SD & $\begin{array}{l}\text { Mean } \\
\text { difference }\end{array}$ & $t$ & $p$ & $d f$ \\
\hline Knowing the existence of UKM & Male & 4.45 & 0.99 & -0.25 & -3.09 & 0.00 & 242.58 \\
& Female & 4.67 & & & & & \\
UKM as a prestigious university & Male & 3.99 & 0.95 & -0.23 & -2.75 & 0.04 & 280.17 \\
& Female & 4.22 & 0.70 & & & & \\
UKM research university status & Male & 3.81 & 1.06 & -0.31 & -3.37 & 0.00 & 280.24 \\
& Female & 4.12 & 0.79 & & & & \\
UKM's mission to uphold the Malay & Male & 3.69 & 1.21 & -0.20 & -1.92 & 0.00 & 301.73 \\
language & Female & 3.90 & 0.99 & & & & \\
UKM offers engineering programs & Male & 3.93 & 1.12 & -0.12 & -1.16 & 0.00 & 305.48 \\
& Female & 4.05 & 0.93 & & & & \\
UKM has quality engineering program & Male & 3.68 & 1.07 & -0.15 & -1.57 & 0.00 & 288.74 \\
& Female & 3.83 & 0.82 & & & & \\
UKM offers dual-degree program & Male & 2.98 & 1.30 & -0.13 & -1.13 & 0.01 & 310.82 \\
& Female & 3.11 & 1.09 & & & & \\
UKM engineering programs are more & Male & 3.17 & 1.06606 & -0.08 & -0.82 & 0.03 & 306.39 \\
difficult & Female & 3.25 & 0.87186 & & & & \\
\hline
\end{tabular}

Based on the table 2, they agreed that they recognized the existence of UKM as prestigious university offering competency programs $(\mathrm{t}(280.17)=-2.75, p<0.05)$, UKM is one of the research university $(\mathrm{t}(280.23)=-3.37, p$ $<0.05)$, and is offering engineering programs $(\mathrm{t}(305.48)=-1.16, p<0.05)$. For the remaining items, the mean was 4.0000 and the items with the mean below than 4.0000 were identified negative responses from the respondents. It was obvious that both male and female respondents had lack knowledge about dual degree programs offered by UKM with $\mathrm{t}(310.82)=-1.13, p<0.05$.

The same test was used in PART C to analyze the respondents' responses regarding their interest towards the engineering programs offered by UKM. Only responses from 170 respondents comprised $87(51.20 \%)$ male and $83(48.80 \%)$ female were taken into account. These respondents were those who had interest in pursuing the engineering programs at the FEBE, UKM. The remaining respondents who did not choose to continue their studies in engineering programs were excluded in this analysis. The objective was to identify the level of interest of the respondents accurately. The data was analysed to observe the trend based on gender as shown in Table 3 .

Table 3. Interest of the respondents towards engineering programs at UKM

\begin{tabular}{llllllll}
\hline PART C & Gender & M & SD & $\begin{array}{l}\text { Mean } \\
\text { difference }\end{array}$ & $t$ & $p$ & $d f$ \\
\hline Interest in the engineering programs at & Male & 4.09 & 1.11 & 0.32 & 2.78 & 0.00 & 320.83 \\
UKM & Female & 4.06 & 0.98 & & & & \\
Interest to further studies in Electrical and & Male & 3.09 & 1.17 & 0.19 & 1.75 & 0.02 & 316.59 \\
Electronic Engineering & Female & 3.14 & 1.21 & & & & \\
Choose an engineering programs at other & Male & 4.11 & 1.07 & 0.53 & 4.15 & 0.01 & 299.20 \\
university & Female & 3.60 & 1.16 & & & & \\
If not selected for engineering, choose other & Male & 3.08 & 1.24 & -0.41 & -3.47 & 0.78 & 457.00 \\
programs at UKM & Female & 3.25 & 1.26 & & & & \\
Engineering programs at UKM, although & Male & 3.76 & 1.15 & -0.03 & -0.23 & 0.10 & 483.00 \\
not preferred & Female & 3.72 & 1.07 & & & & \\
\hline
\end{tabular}

Overall, the respondents only showed significant correlations in the items that measured their interest to pursue 
engineering programs at UKM $(\mathrm{t}(320.83)=2.78, \mathrm{p}<0.05)$, their interest to further studies in Electrical and Electronic Engineering $(\mathrm{t}(316.60)=1.75, \mathrm{p}<0.05)$ and their possibilities of choosing other universities if they were not offered to further engineering programs at UKM $(\mathrm{t}(299.20)=4.15, \mathrm{p}<0.05)$.

\subsection{Selection Factors for University and Programs of Study}

PART D was divided into three sections: i) items that influence the selection of universities and programs of study, ii) preferred university criteria, and iii) preferred program criteria. The analysis was carried out separately to examine about the selection of university and study program among the respondents more accurately. Based on the data in PART C, the mean comparison method was used for the analysis to observe the trend of the respondents' decisions based on gender. The results for the three sections were shown in Table to Table 6 .

Table 4. Factors affecting the selection of the universities and programs of study

\begin{tabular}{lllll}
\hline Section A & Gender & $\mathrm{N}$ & $\mathrm{M}$ & $\mathrm{SD}$ \\
\hline The influence of parents, teachers and family members & Male & 87 & 3.98 & 1.10 \\
& Female & 83 & 3.81 & 1.14 \\
Follow friend's selections & Male & 87 & 2.94 & 1.17 \\
& Female & 83 & 2.52 & 1.06 \\
Suitability with personality and interest & Male & 87 & 4.26 & 0.81 \\
& Female & 83 & 4.01 & 1.03 \\
Information from media & Male & 87 & 3.38 & 0.90 \\
& Female & 83 & 3.81 & 0.88 \\
Career history & Male & 87 & 3.38 & 1.24 \\
& Female & 83 & 3.24 & 1.16 \\
The cost of study and financial support & Male & 87 & 3.95 & 1.03 \\
The cost of study and financial support & Female & 83 & 3.75 & 1.14 \\
& Male & 87 & 3.98 & 1.10 \\
\hline
\end{tabular}

Table 5. Criteria of preferred university

\begin{tabular}{lllll}
\hline Section B & Gender & $\mathrm{N}$ & $\mathrm{M}$ & $\mathrm{SD}$ \\
\hline Good reputation of the university & Male & 87 & 4.49 & 0.83 \\
University location close to parents & Female & 83 & 4.53 & 0.59 \\
& Male & 87 & 3.06 & 1.29 \\
University location near the city centre & Female & 83 & 3.00 & 1.24 \\
& Male & 87 & 3.64 & 1.19 \\
Competitiveness of entry requirements & Female & 83 & 3.52 & 1.09 \\
& Male & 87 & 4.05 & 0.90 \\
University status & Female & 83 & 3.76 & 0.95 \\
Competitiveness of programs offered & Male & 87 & 4.37 & 0.79 \\
& Female & 83 & 4.05 & 0.81 \\
University facilities & Male & 87 & 4.22 & 0.78 \\
Competent academicians & Female & 83 & 3.96 & 0.79 \\
& Male & 87 & 4.29 & 0.79 \\
& Female & 83 & 4.24 & 0.76 \\
& Male & 87 & 4.53 & 0.74 \\
\hline
\end{tabular}


Table 6. Criteria of preferred programs

\begin{tabular}{lllll}
\hline Section C & Gender & $\mathrm{N}$ & $\mathrm{M}$ & $\mathrm{SD}$ \\
\hline Career opportunities in the future & Male & 87 & 4.68 & 0.71 \\
& Female & 83 & 4.58 & 0.68 \\
Interest in selected areas & Male & 87 & 4.61 & 0.74 \\
& Female & 83 & 4.51 & 0.76 \\
Starting salary & Male & 87 & 4.09 & 0.91 \\
& Female & 83 & 4.20 & 0.78 \\
Popularity career & Male & 87 & 3.69 & 1.00 \\
& Female & 83 & 3.64 & 1.05 \\
The duration of study & Male & 87 & 3.83 & 0.95 \\
& Female & 83 & 3.98 & 0.80 \\
Gradient studies & Male & 87 & 3.78 & 0.97 \\
\multirow{2}{*}{ Competent trainers } & Female & 83 & 3.76 & 0.92 \\
Performance in secondary school subjects & Male & 87 & 4.43 & 0.84 \\
& Female & 83 & 4.35 & 0.72 \\
The involvement of family members in the field of choice & Male & 87 & 3.90 & 1.09 \\
& Female & 83 & 3.34 & 1.26 \\
\hline
\end{tabular}

From the results, it was found that the respondents, regardless of the gender, were concerned about the suitability of study programs with their personalities and interest with the most dominant mean value $\mathrm{M}=4.26, \mathrm{SD}=.81$ and $\mathrm{M}=4.01, \mathrm{SD}=1.03$ for male and female respondents, respectively. Whereas, the university selection which was based on friend's choices recorded the mean value of $\mathrm{M}=2.94, \mathrm{SD}=1.17$ for male and $\mathrm{M}=2.52, \mathrm{SD}=$ 1.06 for female suggesting that this factor did not affect the respondents in choosing universities and programs of study. Other factors with the mean value below than $4.00(\mathrm{M}=4.00)$ indicated that these factors were not significantly affected the respondents' decisions.

Almost all items listed in Table 6 had significant influences on the respondents in their decision making. It was found that the mean values for all of the factors were in a range of $3.00 \leq \mathrm{M}<5.00$. For instance, university location that was near to the parents contributed a considerable influence to the female respondents $(\mathrm{M}=3.00$, $\mathrm{SD}=1.24)$ and the male respondents $(\mathrm{M}=3.07, \mathrm{SD}=1.29)$ in their evaluations of the preferred university.

However, there were different preferences between the male and female respondents about the competitiveness of the programs offered and the entry requirements to the university. The male respondents were more concern with these factors in their selection of the preferred university.

Similar results were recorded for the criteria of the preferred programs. The generated mean values were in a range of $3.00<M<5.00$. There was no significant difference between the gender observed and they had similar perspectives especially for the career opportunities in the future and their interest. The mean values of the career opportunities criteria for the male and female respondents were $\mathrm{M}=4.68, \mathrm{SD}=0.71$ and $\mathrm{M}=4.58, \mathrm{SD}=0.68$, respectively. While the mean values of the interest criteria for male and female respondents were $\mathrm{M}=4.61, \mathrm{SD}=$ 0.74 and $\mathrm{M}=4.51, \mathrm{SD}=0.76$, respectively.

\section{Discussion}

According to the results obtained, the matriculation students showed a moderate level of knowledge about UKM and its engineering programs. The most noteworthy information acquired was that some of them did not know about the dual degree programs offered by the university even though the collaboration has been established with the Duisburg-Essen University since 2002 (Universiti Kebangsaan Malaysia, 2011). This suggested that the matriculation students were not widely exposed to UKM from the early stage.

According to Lichtenstein, Loshbaugh, Chen, Jackson, and Sheepard (2009), the perceptions were significantly 
influence the students in making decisions and those who were not exposed to the information will make their decisions based on the limited perceptions. Thus, the exposure is very important because the information will influence them in evaluating the university's reputation more precisely and it is very subjective for each of the individuals. Besides, the students' perceptions towards the engineering programs are also influenced by other factors such as maturity, confidence and their commitment to their studies.

Although only 170 (34.27\%) of the matriculation students showed their interest to pursue engineering programs, these respondents contributed a significant analysis for the factors and criteria in PART D that focus on the factors in choosing the universities and study programs. Separate analysis of the results demonstrated the suitability of the field with the internal values of the individuals, good reputations of the university, career opportunities and interest were among the factors that influence the students (Ming, 2010; Shammot, 2011).

However, there was no significant difference in the trend of the selection based on the students' gender although there were some of the items exhibiting different mean values between the male and female respondents. For example, the female respondents showed less confidence and lack of encouragement from the surroundings in their decision making compared to the male respondents and this finding was consistent with the study from Mustapha and Long (2010). Meanwhile, the male respondents were more concerned with the quality issues in their selection of the influencing factors such as the competitiveness of the programs offered and the entry requirements.

\section{Conclusion}

The findings in this paper were involved the study of the matriculation students from two matriculation colleges under the current economic situation. The findings showed that the male and female students had similar perceptions and interest towards the engineering programs. Several factors that influence the students' decisions in choosing university and undergraduate programs had been identified. Therefore, these findings should be included in the guidelines to increase awareness and deliver comprehensive information to the Malaysian community. Further studies will look into the factors in longitudinal students' decisions to observe how they change over age.

\section{Acknowledgements}

This project is funded by the research grant PTS-2011-008, UKM-OUP-NBT-28-131/201 and OUP-2012-126. Gratitude is addressed to the Matriculation Division, Ministry of Education Malaysia for the cooperation in distributing the questionnaire. This work is supported by the Centre for Engineering Education Research, Faculty of Engineering and Built Environment, Universiti Kebangsaan Malaysia, Bangi, Selangor, Malaysia.

\section{References}

Abu-Saad, I., \& Isralowitz, I. E. (1997). Gender as determinant of work values among university students in Israel. Journal of Social Psychology, 13(7), 749-763. http://dx.doi.org/10.1080/00224549709595496

Ahmad, M. Y. (2010). Malaysia failed to produce an academic icon. Utusan Malaysia. Retrieved from http://jpnpp.edu.my/index.php?

Albion, M. J., \& Fogarty, G. J. (2011). Factors influencing career decision making in adolescents and adults. Journal of Career Assessment, 10(1), 91-126. Retrieved from http://www.jca.sagepub.com; http://dx.doi.org/10.1177/1069072702010001006

Baryeh, E. A., Squire, P. J., \& Mogotsi, M. (2011). Engineering education for women in Bostwana. International Journal of Electrical Engineering Education, 38(2), 173-182.

Christie, H., Munro, M., \& Fisher, T. (2004). Leaving university early: Exploring the difference between continuing and non continuing student. Studies in Higher Education, 29(5), 617-636. http://dx.doi.org/10.1080/0307507042000261580

Duffy, D. R., \& Sedlacek, W. E. (2007). The work values of first year college students: Exploring group

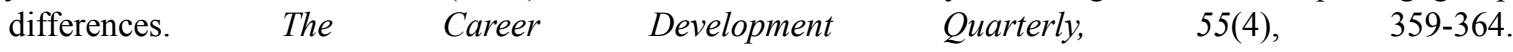
http://dx.doi.org/10.1002/j.2161-0045.2007.tb00090.x

Duffy. D. R., \& Sedlacek. W. E. (2011). What is most important to students' long term career choice: Analyzing 10-year trends and group differecences. Journal of Career Development, 34(2), 149-163. Retrieved from http://www.jcd.sagepub.com; http://dx.doi.org/10.1177/0894845307307472

Economic Development. Third Outline Perspective Plan, 2001-2010. Economic Planning Unit. Retrieved from 
Retrieved from http://www.epu.gov.my/html/themes/epu/images/common/pdf/3rd_OPP_cont_chap6.pdf

Engineering Accreditation Council. Accreditation. List of accredited engineering programme (Malaysia). Retrieved from http://www.eac.org.my/web/list_accredited.html

Faculty of Engineering and Built Environment. (2010). UP3 Committee Report Faculty of Engineering. Universiti Kebangsaan Malaysia.

Faculty of Engineering and Built Environment. (2011). Internationalisation. Universiti Kebangsaan Malaysia. Retrieved from http://www.ukm.my/jurutera/index.php/undergraduates/internationalisation

Hassan, M. (2008). Factors influencing students' choice of higher institutions of learning. Gombak: International Islamic University Malaysia.

Jusoh, N. (2006). The study of matriculation students selection factors to the local university and educational courses. Bachelor dissertation, Faculty of Education, Universiti Teknologi Malaysia.

Lichtenstein, C., Loshbaugh, H. G., Chen, H. L., Jackson, K., \& Sheppard, S. D. (2009). An engineering major does not (necessarily) an engineer make: Career decision making among undergraduate engineering majors. Journal of Engineering Education, 98(3), 227-234.

Looker, E. D., \& Lowe, G. S. (2001). Post secondary access and student financial aid in Canada: Current knowledge and research gaps. Paper presented at Canadian Policy Research Networks Workshop on Post Secondary Access and Student Financial Aid, in Ottawa.

Mahani, S., \& Molki, A. (2011). Factors influencing female Emirati students' decision to study engineering. Global Journal of Engineering Education, 13(1), 26-31.

Mastor, K. A. (2006). Introvert personality and decision making psychology among Malay students. Journal of General Studies, 7, 67-80.

Matusovich, H. M., Streveler, R. A., \& Miller, R. L. (2010). Why do students choose engineering? A qualitative, longitudinal Investigation of students' motivational values. Journal of Engineering Education, 99(4), 289-303.

McInnis, C., James, R., \& Hartley, R. (2000). Trends in first year experience. Evaluation and investigation program, Higher Education Division on 00 / 6. Canberra: Department of Education, Training and Youth Fair,

Ming, J. S. K. (2010). Institutional factors influencing college students choice decision in Malaysia: A conceptual framework. International Journal of Business and Social Science, 1(3) 53-58.

Ministry of Higher Education. Higher Education Strategic Plan. Publishing. Retrieved from http://www.mohe.gov.my/psptn/index.php?option=com_content\&view=article\&id=50\&Itemid=30

Misran, N., Aziz, N. A., Arsad, N., Hussain, H., Zaki, W. M. D. W., \& Sahuri, S. N. S. (2011). Influencing factors of matriculation students in selecting university and program of study. Paper presented at Universiti Kebangsaan Malaysia Teaching and Learning Congress, 17-20 December, in Penang.

Mustapha, R., \& Long, N. L. (2009). Education for diverse learners. Serdang: Universiti Putra Malaysia Publisher.

Mustapha, R., \& Long, N. L. (2010). Career decision process among women in technical fields. Paper presented at the 1st International Conference on Technical and Vocational Education and Training, 10-11 November, in Bandung.

Noah, S. M. (2008). Testing and evaluation in counseling: Theory and applications. Serdang: Universiti Putra Malaysia Publisher.

Othman, F. (2006). The relationships between family socioeconomic status and student achievement of mathematic in two schools at Johor Bahru district. Bachelor dissertation, Faculty of Education, Universiti Teknologi Malaysia.

Sam, L. C., \& Mang, K. C. (2010). The research validity and reliability. In Idris, N. (Ed.), Research in education. Kuala Lumpur: Mc Graw-Hill.

Sanz de Acedo, L. M. L., Sanz de Acedo, B. M. T., \& Cardelle-Elawar, M. (2007). Factors that affect decision making: gender and age difference. International Journal of Psychology and Psychological Therapy, 7(3), 381-391. 
Seymour, E., \& Hewitt, N. M. (1997). Talking about leaving: Why undergraduates leave the sciences. Boulder. CO: Westview Press.

Shammot, M. M. (2011). Factors affecting the Jordanian students' decision Selection among private universities. Quarterly Journal of Business Studies, 2(3), 57-63.

Sulaiman, K. (2008). Sheikh Muzhaphar icon of knowledge. Utusan Malaysia. Retrieved from http://ww2.utusan.com.my/utusan/special.asp?pr $=$ space $\& \mathrm{y}=2008 \& \mathrm{dt}=\& \mathrm{pub}=1214 \& \mathrm{sec}=$ astronauts News \& pg = ab_05.htm

Von Mizener, B. H., \& Williams, R. L. (2011). The effects of student choices on academic performance. Journal of Positive Behavior Interventions, 11(2), 110-128. Retrieved from http://www.pbi.sagepub.com; http://dx.doi.org/10.1177/1098300708323372

Wagner, K., \& Fard, P. Y. (2009). Factors influencing Malaysian students' intention to study at a higher educational institution. New York: E Leader.

Yorke, M. (1999). Cambodian students and motivation to participate in higher education. Querying Education Society, 17(2), 85-98. 